\title{
Analysis of Wind Influence to Radio Astronomy Observations at Irbene Radio-telescope Complex
}

\author{
Sabine Upnere ${ }^{1}$, Normunds Jekabsons ${ }^{2},{ }^{1-2}$ Ventspils University College, Roberts Joffe, Lulea University of \\ Technology, Ventspils University College, Valerijs Bezrukovs, Institute of Physical Energetics, Ventspils University \\ College, Vladislavs Bezrukovs, Ventspils University College
}

\begin{abstract}
The results of modelling wind-related deformations in an RT-16 radio telescope (located at Irbene, Latvia) mirror system are presented. The Finite Volume method is used for the development of a Computational Fluid Dynamic model of turbulent airflow around the telescope. An open sourced Computational Fluid Dynamic toolkit OpenFOAM is used for the solution of Partial Different Equations. Notable model difficulties arise due to the open nature of the air flow leading to unknown far field turbulence parameters. Our future plans are to create a unified, coupled, liquid-solid interaction model for RT-32/RT-16 antennas.
\end{abstract}

Keywords - Computational Fluid Dynamic, k-epsilon turbulence model, radio telescope RT-16, wind load

\section{INTRODUCTION}

The Engineering Research Institute "Ventspils International Radio Astronomy Centre" of the Ventspils University College (VIRAC) operates two parabolic, fully steerable radio telescopes RT-32, $32 \mathrm{~m}$ antenna with a surface area of $800 \mathrm{~m}^{2}$ and RT-16, $16 \mathrm{~m}$ antenna with a surface area of $201 \mathrm{~m}^{2}$.

Radio astronomical observations are very sensitive to surface precision and even small deformations may significantly reduce the performance of the antenna. The radio telescope construction affects various loading types: gravity load, wind load and thermal effects (temperature variation).

The three-dimensional, beam-based digital model of the RT-16 has been developed at VIRAC. The results were obtained when the antenna structure deforms only under its own weight. The Finite Element method was used for stress analysis. The results were presented at [9]. The Computational Fluid Dynamic (CFD) model was created for the implementation of turbulent airflow around the telescope by using the coordinates of the reflector surface of the beambased digital model.

The research plans to study the effect of wind loads on the RT-16 radio telescope's main reflector in two subsequent steps. First, a general CFD model was established. Simulation was carried out using wind speed measurement data obtained in Irbene. The second step includes the development of a unified, coupled, liquid-solid interaction which is work in progress. The general objective of this work is to evaluate the effect of wind load on the antenna structure using the CFD model and wind speed statistical data in the vicinity of the observatory.

In this study, the open source CFD toolkit OpenFOAM (Open Field Operation and Manipulation) was used for resolving partial differential equations. Due to the complexity, numerical simulations were carried out on a multi-processor, Linux-based computational cluster with OpenFOAM based CFD solvers.

\section{CFD MODEL OF TURBULENT FLOW}

\section{A. General Statement}

The standard CFD approach is used in the study. Methods of CFD are built upon the fundamental governing equations: the energy equation is based on energy conservation; NavierStokes equations - the continuity equation based on mass conservation, the momentum equations based on Newton's second law of motion.

In this case, fluid flow has a relatively low speed, thus air density is almost constant and wind flow at the telescope can be considered as incompressible. The equation of continuity reads as [5]

$$
\operatorname{div} \boldsymbol{u}=0
$$

Since the temperature changes near the telescope are negligible, the energy transfer equation is neglected. Impulse conservation equations will be discussed below.

\section{B. Turbulence Modelling}

Several approaches are known for the CFD simulations of turbulent flows, for example, Direct Numerical Simulations (DNS), Reynolds-averaged Navier-Stokes (RANS) models and Large Eddy Simulation (LES). In a DNS, all the spatial scales, ranging from the smallest dissipative scale to the integral scale of the flow are associated with the motions containing most of the kinetic energy and need to be resolved directly in the computational mesh. A three-dimensional DNS requires a number of mesh points $N^{3}$ satisfying [4]

$$
N^{3} \geq R e_{\tau}^{2.25}
$$

where the turbulent Reynolds number $\left(R e_{\tau}\right)$ is defined as [4]

$$
R e_{\tau}=\frac{\mathrm{u}^{\prime} \cdot \mathrm{L}}{v}
$$

As follows from (2) and (3), the requirement for computing resources in a DNS grows with the Reynolds number. For this particular system, the estimated $R e_{\tau}$ is $3.3 \cdot 10^{8}$ and $N^{3} \geq$ $3.3 \cdot 10^{18}$, therefore the DNS approach is not appropriate. Due to limited CPU time and human resources, the RANS-based 
turbulence models were chosen. Based on the value of $R e$, the flow can be considered as turbulent.

The nonlinearity of the Navier-Stokes equations gives rise of the so-called Reynolds stress tensor $\tau_{i j}^{\prime}=\rho \overline{u_{\imath}^{\prime} u_{\jmath}^{\prime}}$. Seminal work by Kolmogorov (1941) argued that small scale turbulence can be characterized by two numbers, the energy dissipation per unit mass, and the kinematic viscosity [3], later two-equation models were introduced.

The two-equation turbulence models chosen for this study are the standard $k-\varepsilon$ model and the RNG (ReNormalisation Group) $k-\varepsilon$ model. In these models for the Navier-Stokes solver, the turbulent viscosity $\nu_{T}(4)$ is needed. The value is obtained from two quantities, the turbulent kinetic energy $k$ and dissipation rate $\varepsilon$, as

$$
v_{T}=C_{\mu} \rho \frac{k^{2}}{\varepsilon}
$$

The standard $k-\varepsilon$ model (Hanjalic and Launder, 1972) is considered as the industry standard [6]. The RNG (Yakhot and Orzag, 1986) $k-\varepsilon$ model was used as an alternative turbulence model.

The two-equation turbulence models consist of the mass conservation equation, impulse conservation equations, and two transport equations for the turbulent kinetic energy $\mathrm{k}$ (5) and dissipation rate $\varepsilon(6)$. The standard mass conservation equation and the momentum conservation equations for $k-\varepsilon$ turbulence models were used, see [6].

The standard $k-\varepsilon$ model has the following transport equations:

$$
\frac{\partial k}{\partial t}+u_{j} \frac{\partial k}{\partial x_{j}}=\nabla \cdot\left(\frac{\nu_{T}}{\sigma_{k}} \nabla k\right)+P-\varepsilon
$$

and

$$
\frac{\partial \varepsilon}{\partial t}+u_{j} \frac{\partial \varepsilon}{\partial x_{j}}=\nabla \cdot\left(\frac{v_{T}}{\sigma_{\varepsilon}} \nabla \varepsilon\right)+C_{\varepsilon 1} \frac{P \varepsilon}{k}-C_{\varepsilon 2} \frac{\varepsilon^{2}}{k}
$$

where $P$ is the turbulent production. $k-\varepsilon$ model are used with the following standard constant values [1]: $C_{\mu}=$ 0.09; $C_{\varepsilon 1}=1.44 ; C_{\varepsilon 2}=1.92 ; \sigma_{k}=1.0 ; \sigma_{\varepsilon}=1.3$. The RNG model turbulent kinetic energy transport equation is identical as the standard $k-\varepsilon$, but the second equation is modified as follows:

$$
\frac{\partial \varepsilon}{\partial t}+u_{j} \frac{\partial \varepsilon}{\partial x_{j}}=\nabla \cdot\left(\frac{\nu_{T}}{\sigma_{\varepsilon}} \nabla \varepsilon\right)+C_{\varepsilon 1} \frac{P \varepsilon}{k}-C_{\varepsilon 2}^{*} \frac{\varepsilon^{2}}{k}
$$

where

$$
\begin{gathered}
C_{\varepsilon 2}^{*}=C_{\varepsilon 2}+\frac{C_{\mu} \eta^{3}\left(1-\frac{\eta}{\eta_{0}}\right)}{1+\beta \eta^{3}}, \\
\eta=\frac{\sqrt{2 S_{i j} S_{i j}} k}{\varepsilon}, \\
S_{i j}=\frac{1}{2}\left(\frac{\partial u_{i}}{\partial x_{j}}+\frac{\partial u_{j}}{\partial x_{i}}\right) .
\end{gathered}
$$

The model constants for $R N G k-\varepsilon$ model are: $C_{\mu}=$ $0.0845 ; C_{\varepsilon 1}=1.42 ; C_{\varepsilon 2}=1.68 ; \sigma_{k}=1.39 ; \sigma_{\varepsilon}=$ $1.39 ; \eta_{0}=4.38 ; \beta=0.012$.

\section{Boundary Conditions}

Five boundaries were defined in the model (see Fig. 1).

\begin{tabular}{|c|c|c|}
\hline $\begin{array}{l}\text { Boundary names } \\
\text { (see Fig. 1) }\end{array}$ & Pressure & Velocity \\
\hline reflector & $\frac{\partial p}{\partial n}=0$ & $u=(0,0,0)$ \\
\hline free & $\frac{\partial p}{\partial n}=0$ & $\begin{array}{l}\frac{\partial u_{t}}{\partial n}=0 \\
u_{n}=0\end{array}$ \\
\hline ground & $\frac{\partial p}{\partial n}=0$ & $u=(0,0,0)$ \\
\hline inlet & $\frac{\partial p}{\partial n}=0$ & $u=$ const \\
\hline outlet & $p=0$ & $\frac{\partial u}{\partial n}=(0,0,0)$ \\
\hline
\end{tabular}

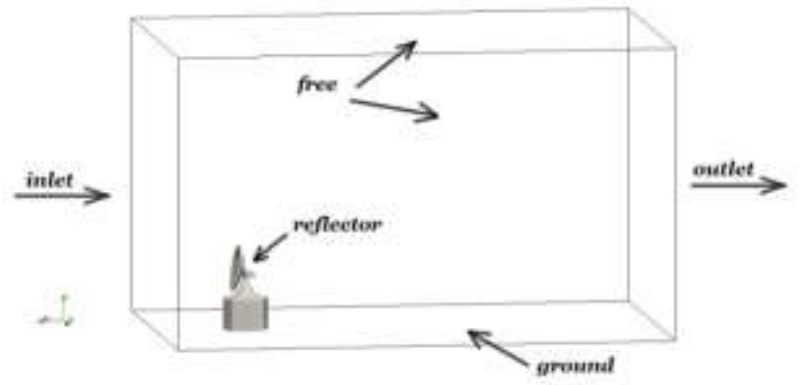

Fig. 1. General view of the computational domain with boundary names.

The applied boundary conditions (BC) are summarized in Table I.

TABLE I

BOUNDARY CONDITIONS

Pressure on the outlet boundary is set to zero. Due to the friction at the wall, the velocity of the flow is zero on the ground and on the surface of the telescope. Since the computational domain is assumed to be embedded in the sublayer of the atmospheric boundary layer, the logarithmic velocity profile is applied on the inlet (see the details below).

For simulations with the two-equation turbulence models, the boundary conditions for the turbulence should preferably be described in terms of the turbulence kinetic energy $k$ and the turbulence dissipation rate $\varepsilon$ [8]. The proposed inlet boundary condition for the turbulence kinetic energy and the turbulence dissipation rate is a constant value over the full height of the computational domain, which might not correspond to the profiles measured in the atmosphere. In the present study, the inlet k-profile is determined as follow [8]:

$$
k=\frac{3}{2}(U I)^{2}
$$

where $I$ is the initial turbulence intensity and $U$ is the maximum inlet velocity. The inlet conditions of $\varepsilon$ are given by: 


$$
\varepsilon=C_{\mu}^{3 / 4} k^{3 / 2} l^{-1}
$$

where $l=0.07 L_{c}$ is the turbulence length scale. The others $\mathrm{BC}$ of $k$ and $\varepsilon$ were obtained by $(\nabla k, n)=0$ and $(\nabla \varepsilon, n)=0$.

\section{Inlet Velocity Profile}

In the atmospheric boundary layer where the CFD model is located, the mean horizontal velocity is commonly described by a logarithmic profile in neutral conditions, see [2]. Thermal effects are considered to be negligible. The model inflow velocity $\mathrm{BC}$ is described as follows [5]:

$$
u(z)=\frac{u_{f r}}{K_{\text {const }}} \ln \left(\frac{z-d}{z_{0}}\right)
$$

where $u(z)$ - wind speed at height $z, u_{f r}$ is the friction velocity, $K_{\text {const }}$ is the von Karman constant ( 0.4). The zeroplane displacement height, $d$, is the location above the ground. The aerodynamic roughness length, $z_{0}$, is the height above the ground where the flow velocity is zero. Although $z_{0}$ is slightly dependent on the flow, it is widely accepted to be constant [11]. In this case, $z_{0}$ is 0.1 which is suitable in relation to the following landscape types: agricultural land, houses, and 8 meter tall sheltering hedgerows with a distance of approximately 500 meters (according to the European Wind Atlas [7]). CFD models use two logarithmic inlet velocities $U_{l}$ and $U_{2}$. Velocity $U_{1}$ corresponds to the average wind speed (see Fig. 2) for the measurement period [10].

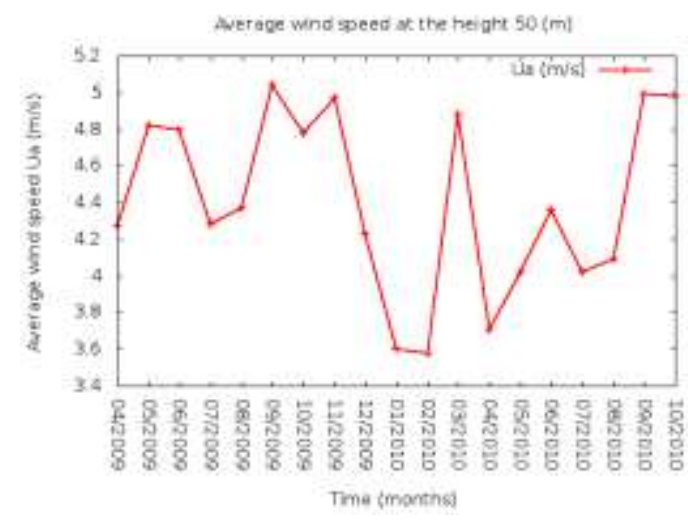

Fig. 2. Average wind speed values for measurements.

$U_{2}$ is the maximum velocity at which the manufacturer has allowed an antenna to be operated (see Fig. 3).

Boundary conditions (13) were implemented as an addition to software toolkit OpenFOAM. The inlet flow velocity was calculated using the average values measured at two reference heights (30 and 50 meters). In order to compare the simulation results with measurements, the sub-model which did not include radio telescope construction was set up.

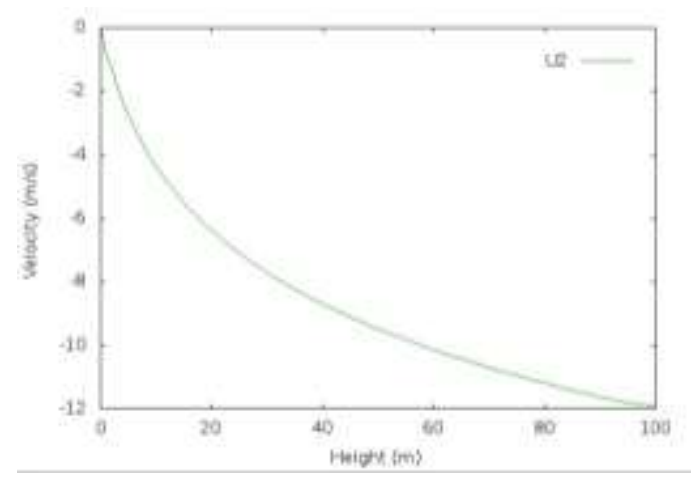

Fig. 3. Inlet velocity profile $U_{2}$.

\section{E. Numerical Implementation}

In order to generate the mesh, two open source preprocessing tools were used: Gmsh 2.5 and OpenFOAM. Gmsh was used to build the antenna geometry and to create the surface mesh. After the mesh was created, it was exported in "stl" (stereolithography) format and transferred to OpenFOAM. The background mesh was initially created in OpenFOAM blockMesh utility and then the final computational domain was assembled using snappyHexMesh (see Fig. 4).

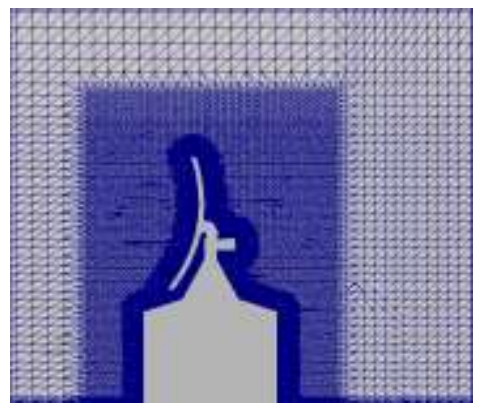

Fig. 4. Mesh around RT-16 telescope.

It is rather impossible to take into account all atmospheric effects of the system; therefore the flow behaviour in the periodic rectangular domain was simulated. The computational domain is sized as follows (width $\mathrm{x}$ height $\mathrm{x}$ length): $112 \times 104 \times 176 \mathrm{~m}^{3}$. It contains a $32.5 \mathrm{~m}$ high RT-16 antenna (see Fig. 1) embedded. The Finite Volume mesh consists of hexahedral and polyhedral elements. The CFD model (see Fig. 5) approximation contains a reflector supporting structure, as well as the simplified representation of a tower.

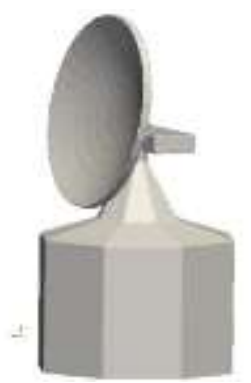

Fig. 5 The Finite Volume model of the RT-16 radio telescope. 
To solve the governing equations, the OpenFOAM-based in-house developed solver was used. Cases of two turbulence models on various antenna pointing angles were studied.

Variable numerical convergence criterion is based on each iteration residuals. OpenFOAM residuals definition lies on scaled residuals theory. For the system:

$$
A x=b
$$

the residual is defined as

$$
R=b-\boldsymbol{A} x
$$

Then the residual scaling is applied with the following normalization factor procedure:

$$
x_{\text {ref }}=\bar{x}
$$

setting temporal variables

$$
\begin{gathered}
w_{A}=\boldsymbol{A} x \\
p_{\boldsymbol{A}}=\boldsymbol{A} x_{r e f}
\end{gathered}
$$

now the scaling factor is:

$$
\text { scaleFactor }=\sum\left|w_{A}-p_{A}\right|+\left|b-p_{A}\right|+\text { matrix }
$$

where matrix $=1.0 \times 10^{-20}$. Then the scaled residual is:

$$
R_{S}=\frac{\sum\left|b-w_{A}\right|}{\text { scaleFactor }}
$$

In these cases, the normalised residuals had to be smaller than $10^{-5}$ for all variables except the pressure, where the residual is smaller than $10^{-6}$.

\section{F. Mesh Quality}

Due to limited resources, in practice the mesh size is always limited. In order to see how the mesh of chosen size performs in terms of solution accuracy and stability, a series of mesh studies was performed. Meshes of $1.4 \cdot 10^{6}, 2.0 \cdot 10^{6}$ and $2.5 \cdot 10^{6}$ points (approximately) are tested. Each mesh has the same basic setup and only the cell size is different. The simpleFoam solver using the $k-\varepsilon$ turbulence model was employed to evaluate these cases. Figure 6 shows mesh test results for each mesh type for $u(x)$ velocity profile at a $40 \mathrm{~m}$ height in the model domain.

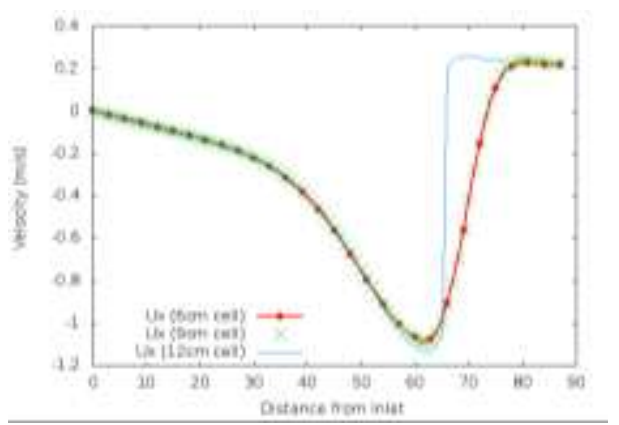

Fig. 6. Mesh study results. Velocity value for tree different mesh sizes.
It can be seen in Fig. 6 that the simulated velocity with 12 $\mathrm{cm}$ cells is different from other cases, but for smaller cell sizes the results almost perfectly coincide, and thus the cell size of 9 $\mathrm{cm}$ is sufficient to ensure good accuracy.

\section{RESULTS AND DISCUSSION}

The CFD calculations were made at different elevation angles, $\alpha_{e}$. The main reflector is rotated around the y-axis. Four values of angle are considered in the current paper $\alpha_{e}=90^{\circ}, 50^{\circ}, 30^{\circ}, 10^{\circ}$ (see Fig. 7, Fig. 5).

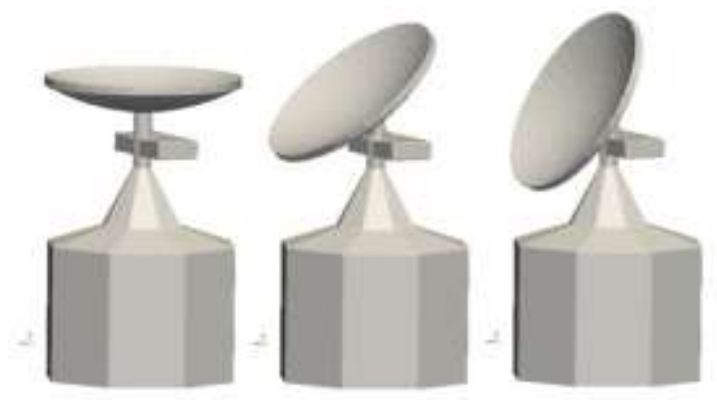

Fig. 7. Elevation angle of main reflector, $\alpha_{e}=90^{\circ}, 50^{\circ}, 30^{\circ}$.

In order to compare the output of different models, the results are sampled along the four centrelines through the domain. These lines are shown in Fig. 8.

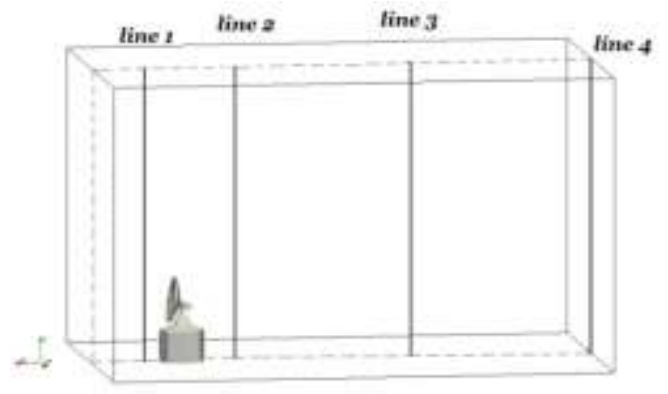

Fig. 8. Lines through the domain where data are collected (cross-section (z-x plane) for $\mathrm{y}=0$ ).

The comparison of $u(x)$ velocity profiles is shown in Fig. 9-11. The comparison of velocity profiles at the two different inlet velocities, $U_{1}$ and $U_{2}$, and at two elevation angles of the main reflector (90 and $10 \mathrm{deg}$ ) is shown in Fig. 9.

The most significant velocity changes occur up to a height of about 40 meters, which is comparable to the radio telescope height (32.5 meters).

When comparing the results obtained with different turbulence intensities $(I=5 \%$ and $I=3 \%)$, the change does not exceed $5.1 \%$ of the maximum value. The results are available in Fig. 10. In these cases, the antenna is rotated at $\alpha_{e}=10^{0}$.

The comparison of the velocity profiles obtained from two turbulence models, $k-\varepsilon$ and $R N G k-\varepsilon$, with an elevation angle of $50 \mathrm{deg}$ is presented in Fig. 11. Similarly to the comparison of different turbulence intensities, in this case, the profile differences are not significant and the maximum difference of $5.6 \%$ over the maximum value is observed. 
(a)

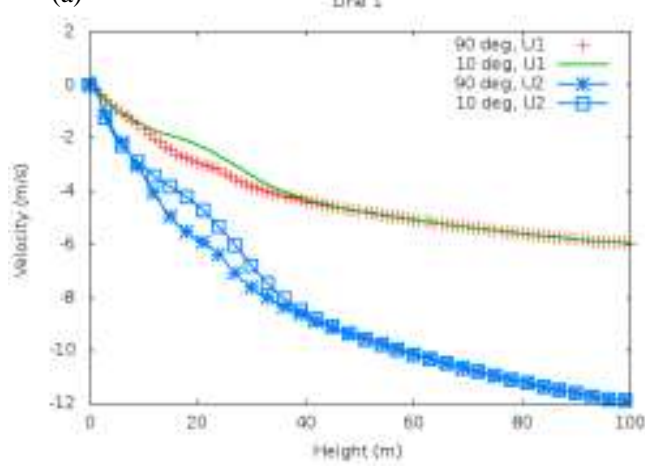

(c)

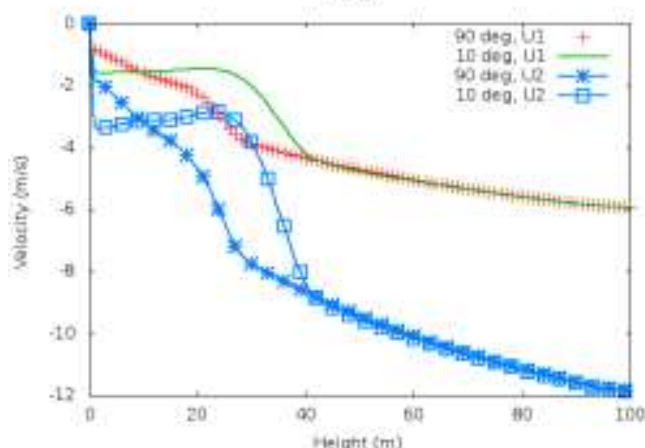

(b)

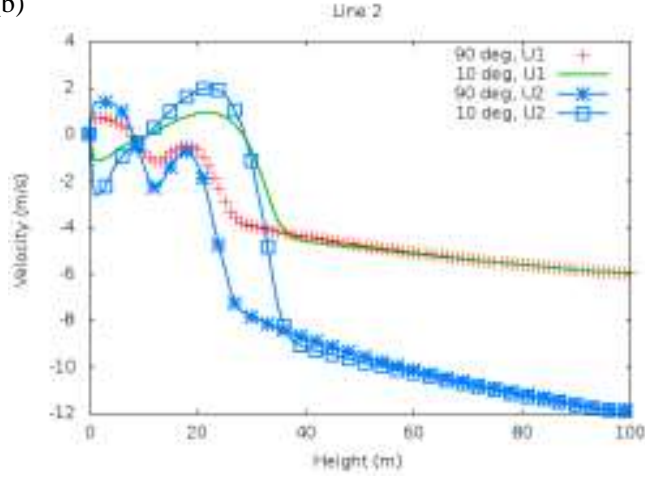

(d)

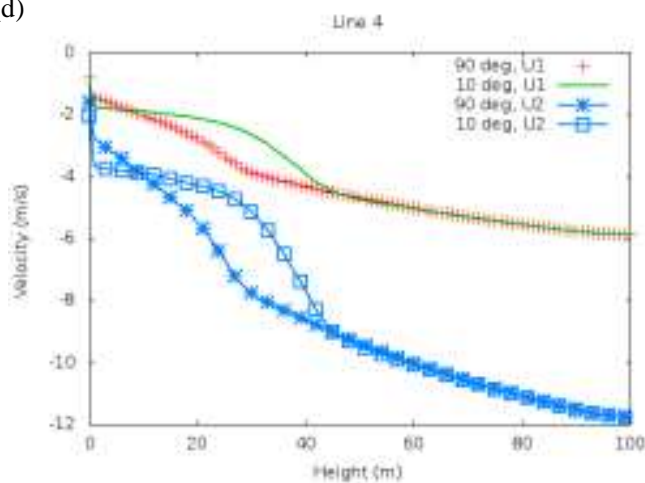

Fig. 9. $u(x)$ velocity profile along four vertical lines at two inlet velocity, $U_{I}$ and $U_{2}$ and two elevation angles, 90 and 10 deg.

(a)

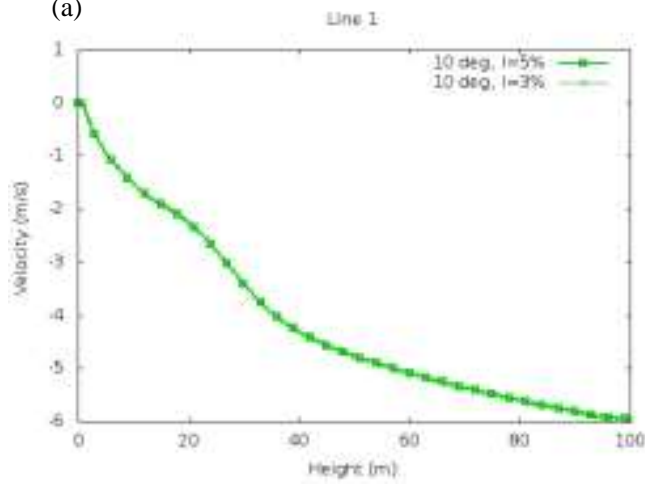

(c)

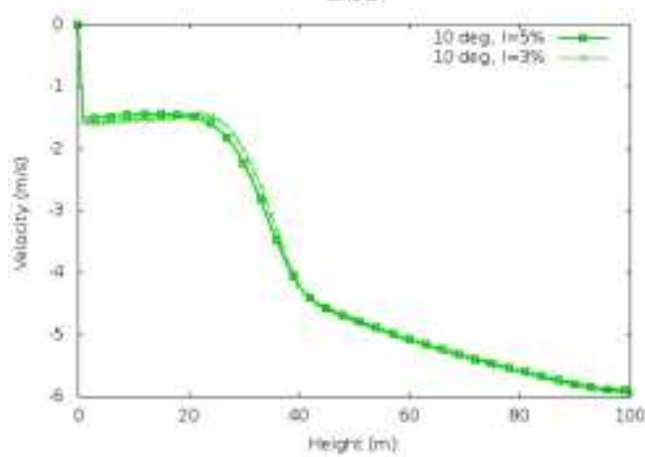

(b)

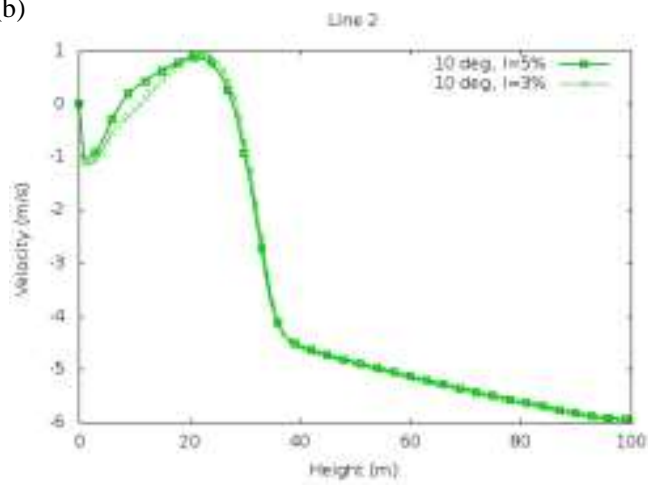

(d)

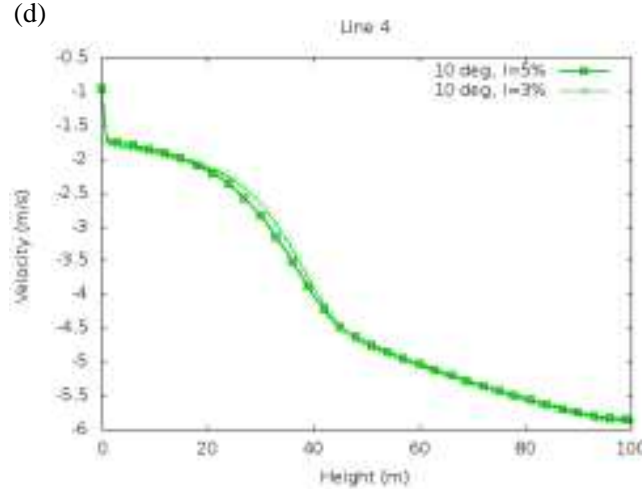

Fig. 10. $u(x)$ velocity profile comparison between two turbulence intensities, $5 \%$ and $3 \%$. 

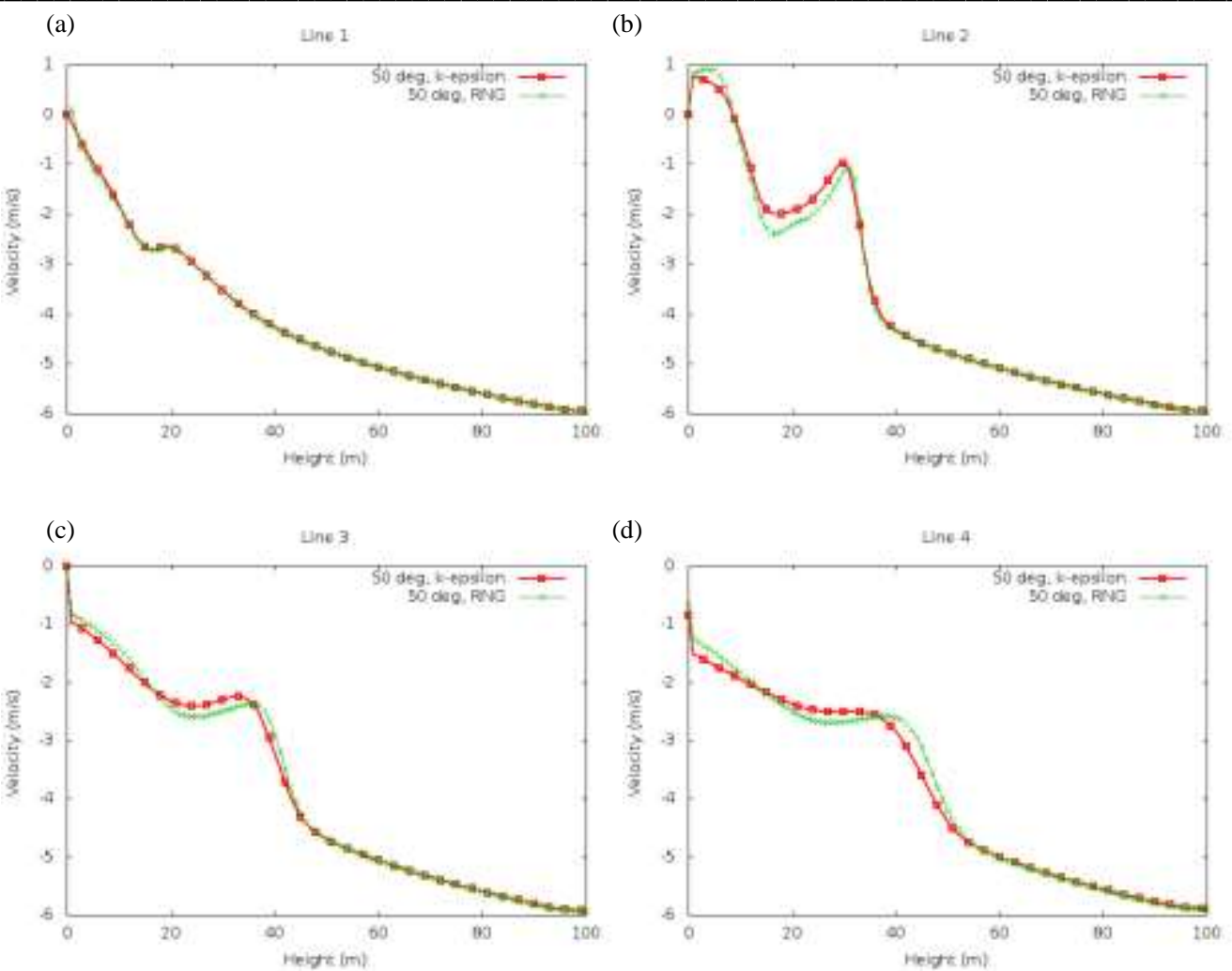

Fig. 11. $u(x)$ velocity profile comparison between two turbulence models, $k-\varepsilon$ and $R N G k-\varepsilon$.

The visualization of flow field traces for every elevation angle under $U_{l}$ wind is shown in Fig. 12. The top view for the reflector upper surface is presented. These results are obtained using the $k-\varepsilon$ turbulence model.

As seen in Fig. 12, the calculated upper flow is symmetric. When the elevation angle is $90^{\circ}$ (see Fig. 12a), the upper flow is massively separated. This trend disappears when the elevation of the angle is decreased (see Fig. 12b, c, d).

The normalized average pressure (20) calculated on the inner and outer main reflector surface is shown in Fig. 13 when the initial velocity is $U_{l}$.

$$
\bar{p}=\frac{p}{\rho}
$$

The difference between the maximum and minimum pressure is from $17 \mathrm{~N} / \mathrm{m}^{2}$ (in Fig. 13a) to $31 \mathrm{~N} / \mathrm{m}^{2}$ (in Fig. 13b).

Table II summarizes the calculated lift $\left(C_{L}\right)$ and drag $\left(\mathrm{C}_{\mathrm{D}}\right)$ coefficients and the lift $(L)$ and drag $(D)$ forces.

TABLE II

CALCULATED LIFT, DRAG COEFFICIENT AND LIFT, DRAG FORCES

\begin{tabular}{|l|l|l|l|l|}
\hline Cases & $\mathrm{C}_{\mathrm{L}}$ & $\mathrm{C}_{\mathrm{D}}$ & $\mathrm{L}(\mathrm{N})$ & $\mathrm{D}(\mathrm{N})$ \\
\hline$\alpha=90^{\circ}$ & 0.053 & 0.040 & 189.38 & 142.12 \\
\hline$k-\varepsilon$ model, $\mathrm{U}_{1}$ & 0.047 & 0.036 & 168.71 & 125.22 \\
\hline$R N G k-\varepsilon$ model, $\mathrm{U}_{1}$ & 0.051 & 0.038 & 726.72 & 546.10 \\
\hline$k-\varepsilon$ model, $\mathrm{U}_{2}$ &
\end{tabular}

\begin{tabular}{|l|l|l|l|l|}
\hline$\alpha=30^{0}$ \\
\hline$k-\varepsilon$ model, $\mathrm{U}_{1}$ & 0.343 & 0.480 & 1206.9 & 1690.7 \\
\hline$R N G k-\varepsilon$ model, $\mathrm{U}_{1}$ & 0.307 & 0.430 & 1080.7 & 1511.0 \\
\hline$k-\varepsilon$ model, $\mathrm{U}_{2}$ & 0.336 & 0.472 & 4732.0 & 6628.7 \\
\hline$\alpha=10^{0}$ & 0.327 & 0.556 & 1143.4 & 1946.5 \\
\hline$k-\varepsilon$ model, $\mathrm{U}_{1}$ & 0.305 & 0.516 & 1068.7 & 1805.3 \\
\hline$R N G k-\varepsilon$ model, $\mathrm{U}_{1}$ & 0.320 & 0.544 & 4484.8 & 7630.4 \\
\hline$k-\varepsilon$ model, $\mathrm{U}_{2}$ &
\end{tabular}

It can be observed from Table II that the increase of the input speed from $U_{1}$ to $U_{2}$ causes an increase in lift and drag forces by a factor of approximately three (x3).

The drag coefficient was defined as [5]

$$
C_{D}=F / \frac{1}{2} \rho U^{2} \cdot 2 l
$$

and the lift coefficient was given by

$$
C_{L}=F / \frac{1}{2} \rho U^{2} \cdot l_{x} l_{y}
$$

The overall inner and outer surface area of the reflector was used to calculate the total force $(F)$.

Case studies were done for elevation angles of 10, 30 and $90 \mathrm{deg}$, inlet velocity $U_{1}$ and $U_{2}$. All calculations are performed with $R N G k-\varepsilon$ and standard $k-\varepsilon$ turbulence models. 
(a)

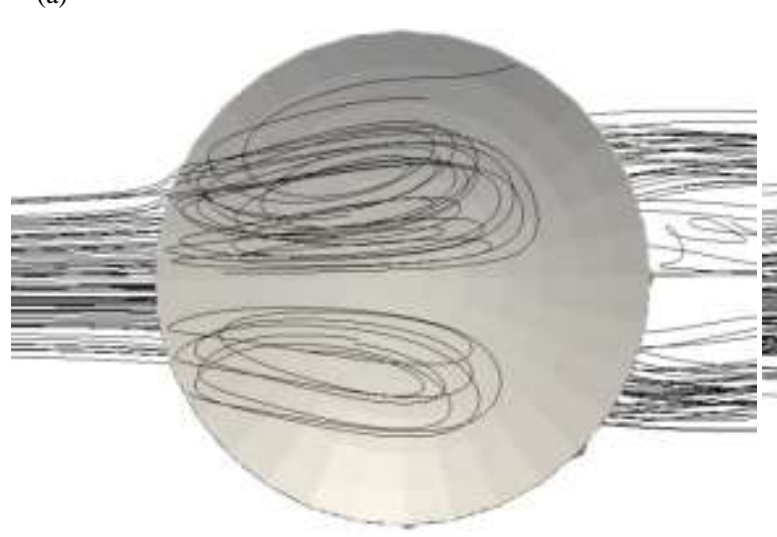

(c)

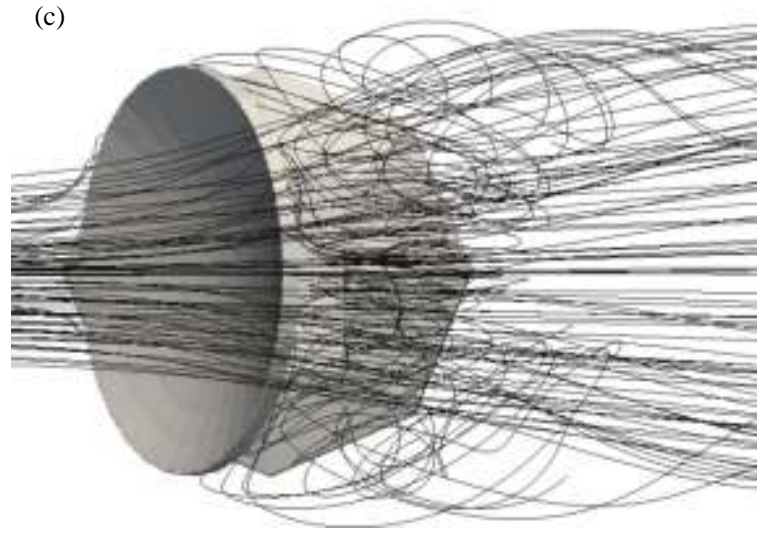

(b)

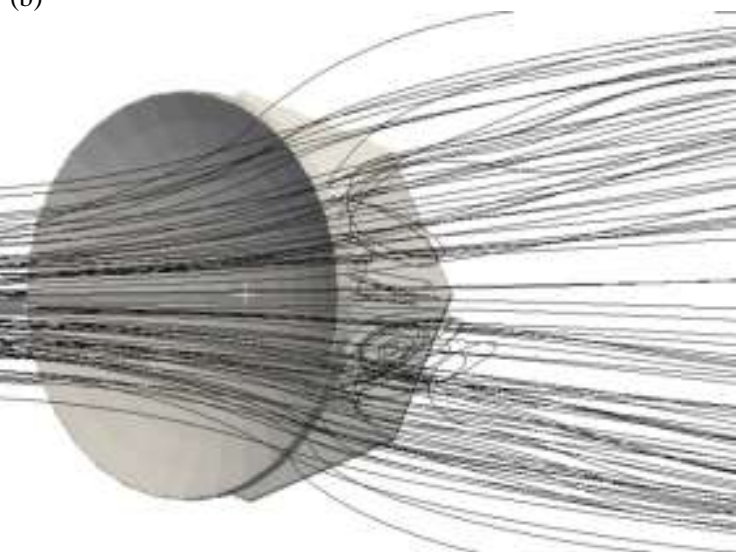

(d)

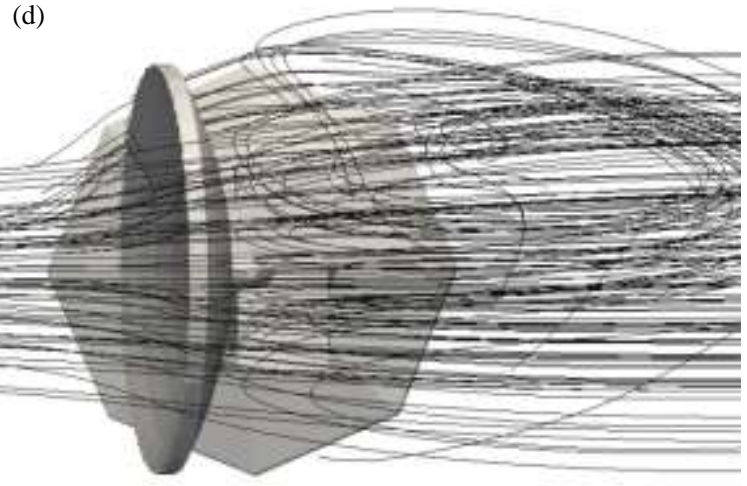

Fig. 12. Flow field top view visualisation, $k-\varepsilon$ turbulence model. (a) $\alpha_{e}=90^{\circ}$, (b) $\alpha_{e}=50^{\circ}$, (c) $\alpha_{e}=30^{\circ}$, (d) $\alpha_{e}=10^{\circ}$.

(a)

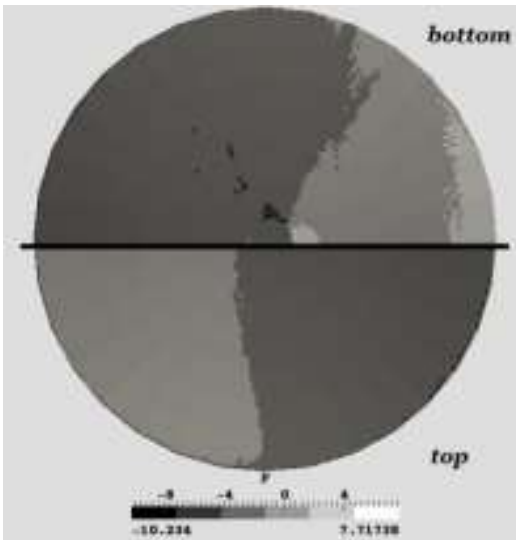

(c)

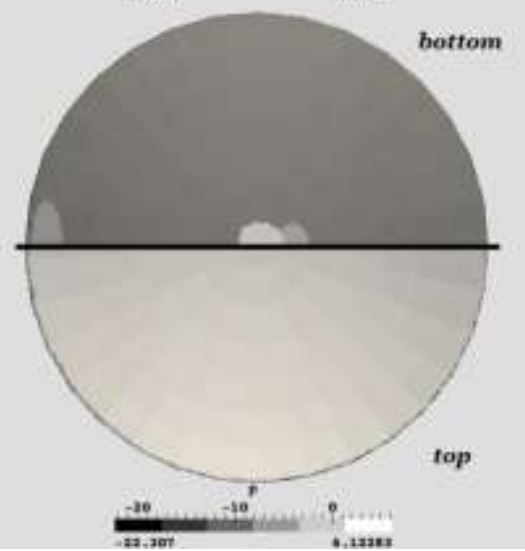

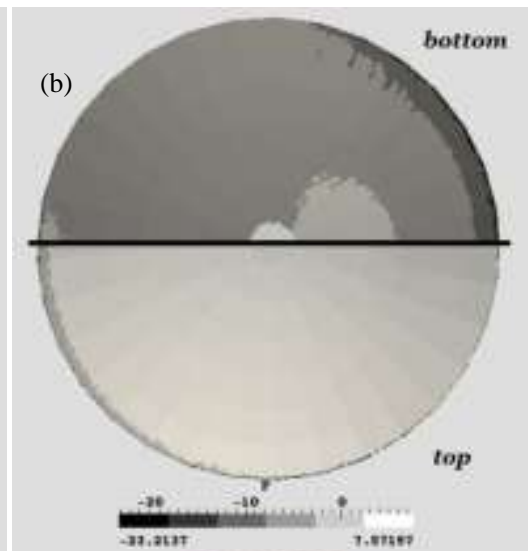

(d)

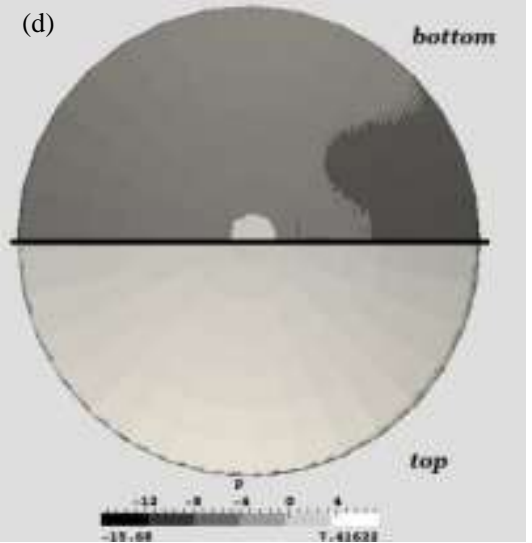

Fig. 13. Reduced average pressure on the main reflector inner and outer surface. (a) $\alpha_{e}=90^{\circ}$, (b) $\alpha_{e}=50^{\circ}$, (c) $\alpha_{e}=30^{\circ}$, (d) $\alpha_{e}=10^{0}$. 


\section{CONCLUSIONS}

1. The $k-\varepsilon$ and $R N G k-\varepsilon$ turbulence models were applied to predict the flow around the radio telescope RT-16 of simplified geometry case. The model convergence was reached to a typical mesh, which give a mesh of $3.41 \cdot 10^{6}$ cells.

2. Two $k-\varepsilon$ type turbulence models were used. A comparison of the output of these models shows that the maximum difference between the pressures is in the 7-9\% range, so the forces acting on the antenna are set with the same or lower accuracy.

3. The total wind flow pressure force depends on the wind speed and the elevation angle $\alpha_{\mathrm{e}}$. For maximum operational wind speed of $10 \mathrm{~m} / \mathrm{s}$, calculations give the following total forces P: $\quad \alpha_{\mathrm{e}}=90$ deg., $\mathrm{P}=1.3(\mathrm{kN}), \quad \alpha_{\mathrm{e}}=30$ deg., $\mathrm{P}=11.36(\mathrm{kN}), \alpha_{\mathrm{e}}=10$ deg., $\mathrm{P}=12.12(\mathrm{kN})$, which can be compared to gravitation force acting on the reflector structure $\mathrm{Pg}=58.80(\mathrm{kN})$. Thus, wind load forces amounts to $22 \%$ of the load level caused by antenna self-weight.

4. The ratio of lift/drag $(L / D)$ forces decreases with a decrease in the antenna elevation angle $\alpha_{e}$ : in the zenith position $\left(\alpha_{e}=90 \mathrm{deg}\right)$, the $L / D$ force ratio is $1.3, \alpha_{e}=30$ deg gives $L / D=0.71$ and $\alpha_{e}=10 \mathrm{deg}$. yields $L / D=0.58$. This result can be explained by the shape of the parabolic dish - at the zenith position it acts similarly to an airplane wing.

5. It can be concluded that the open source toolkit OpenFOAM makes it easy to handle turbulent flow accounts, and the existing solvers can be modified on the case-to-case basis to suit specific needs.

6. The results obtained can be used as input data for a mechanical model to create a unified coupled liquid-solid interaction model.

\section{ACKNOWLEDGEMENTS}

This research was funded by the European Social Fund (project No. 2009/0231/1DP/1.1.1.2.0/09/APIA/VIAA/151).

\section{REFERENCES}

1. Ferziger, J.H., Peric, M. Computational Methods for Fluid Dynamics. Berlin: Springer, 2002. $423 \mathrm{p}$.

2. Garratt, J.R. The Atmospheric Boundary Layer. Cambridge University Press, 1994. 311 p.

3. Gatski, T.B., Hussaini, M.Y., Lumley, J.L. Simulation and modelling of turbulent flows. New York: Oxford University Press, 1996. $314 \mathrm{p}$.

4. Jiang, X., Lai, C. H. Numerical Techniques for Direct and LargeEddy Simulations. London: CRC Press, Taylor \& Francis Group, 2009. $264 \mathrm{p}$.

5. Landau, L.D., Lifshitz, E.M. Fluid Mechanics. Course of theoretical physics; v.6. Oxford: Pergamon Press, $1987.539 \mathrm{p}$

6. Pope, S.B. Turbulent Flows. Cambridge University Press, 2005, p. $373-383$.

7. Troen, I., Petersen, E. L. Europe Wind Atlas. Roskilde: Riso National Laboratory, 1989, 656 p.

8. Gorle, C., van Beeck, J., Rambaud, P., Van Tendeloo G. CFD modelling of small particle dispersion: The influence of the turbulence kinetic energy in the atmospheric boundary layer. Atmospheric Environment, 2009, vol. 43, p. 673-681

9. Jēkabsons, N., Joffe, R., Upnere, S. RT-16 radioteleskopa mehāniskā modeḷa izveide un bojāto element izsaukto deformāciju pētījumi. In 69-th Scientific Conference of the University of Latvia, Rīga, Latvia, February 10, 2011. Abstract.

10. Shipkovs, P., Bezrukov, V., Pugachev, V., Bezrukovs, Vl., Silutins, V. Measurements of the wind energy resource in the Latvia, In World Renewable Energy Congress 2011, 2011, Linkoping, Sweden.

11. Tapia, X. P. Modelling of wind flow over complex terrain using OpenFOAM. Master thesis. Gävle: University of Gävle, 2009, 103 p.

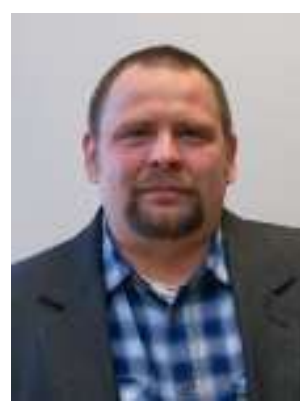

Normunds Jekabsons, PhD. Ventspils University College. Senior researcher in Ventspils International Radio astronomy Center (VSRC). Since 2010, head of high performance computing division in VSRC. The main research areas are Computer Fluid Dynamics, data processing and solid mechanics. Title of his doctoral thesis is "Mechanics of composites with fiber bundle meso-structure", from Luleå University of Technology (Sweden), year 2002. After finishing PhD studies in Sweden (19982002), Normunds Jekabsons has continued his professional work in Latvia. During last nine years participated in several local and international researches and engineering projects.

Address: Inženieru-101, LV-3605, Ventspils, Latvia

Phone: +37126141530

E-mail: normundsj@venta.lv

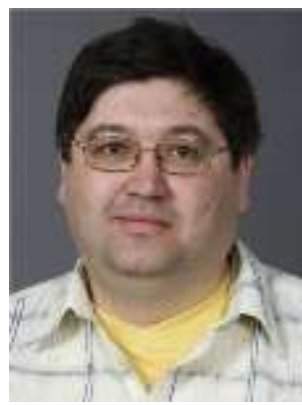

Roberts Joffe, $\mathrm{PhD}$, Associate Professor, Luleå University of Technology (LTU).

Dr Roberts Joffe has been working at LTU as University Lecturer since 2002. The main research area is within mechanics of composites, in particular, mechanisms governing mechanical properties of polymer composites. He has participated in number of national projects as well as in large EC funded projects related to the development of advanced polymer composites and development of nanoand natural composites. He has published 37 papers in international journals and more than 30 contributions in conference proceedings. He has received $\mathrm{MSc}$ in Physics from University of Latvia in 1993; Tech. Lic. in Engineering from LTU in 1996; Ph.D. and Docent degree in Polymeric Composite Materials from LTU in 1999 and 2007 respectively.

Address: Lulea University of Technology, SE-97187, Lulea, Sweden

Phone: +46 920491940

E-mail: Roberts.Joffe@1tu.se

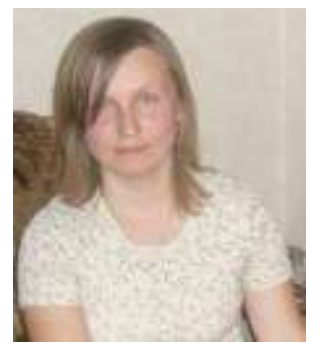

Phone: +37126585324

E-mail: sabineu@venta.lv

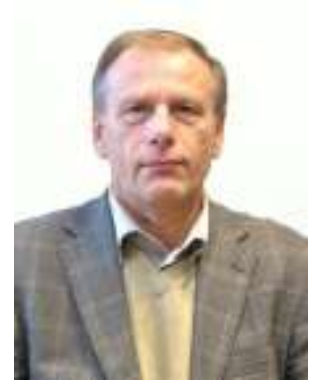

Valerijs Bezrukovs, Dr.hab.sc.ing. Senior researcher in the Institute of Physical Energetics, Riga and in the Engineering Research Institute „Ventspils International Radio Astronomy Centre" of Ventspils University College. Dr. Valerijs Bezrukovs has been part of academic staff of Ventspils International Radio Astronomy Centre since 1994. From 1968 to 1974 he studied in Riga Technical University Electro-Energetics Faculty and specialized in electro mechanics. After diploma he starts work in Latvian Academy of Science in Institute of Physical Energetics, where Valerijs Bezrukovs work on adjusting the synchronous 
motor control systems for use in oil extraction plants. He defend PhD thesis in 1983. In 1987 Valerijs finish Government Advanced Training courses on patenting and elected as head of Institute of Physical Energetics Patenting Department. In 1992 got doctoral degree diploma in VNII electromash, St. Petersburg, Russia. In 1993 got Dr.sc.ing. degree and elected as Senior Researcher in Institute of Physics Energetics where work on electromotor and wind energy fields. Since 1994 work on reconstruction of Irbene radio telescope RT-32 and RT-16. From 2005 the chief engineer and senior researcher at the Ventspils International Radio Astronomy Centre. Research interests: Control of electrical machines, wind energy measurement, acoustic noise of wind parks. More than 70 scientific publications, including 40 patents.

E-mail: valerijs.bezrukovs@venta.lv

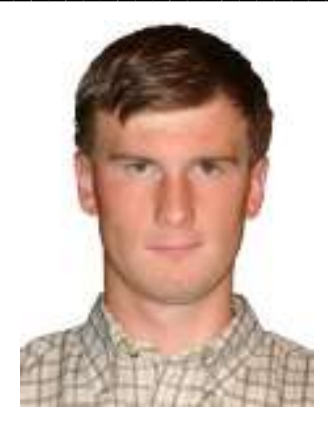

Vladislavs Berzrukovs, Mg.sc.ing., researcher in the Engineering Research Institute „Ventspils International Radio Astronomy Centre" of Ventspils University College. Vladislavs Bezrukovs has been part of academic staff of VIRAC since 2008. The main research areas are radio astronomy and wind studies. He has computer science and computer engineering diploma (2005) and currently work on $\mathrm{PhD}$ thesis "Multiwave length analysis of BL Lacertae objects". He has participated in international projects related to radio astronomy (ENIGMA) and wind energy studies (NORSEWInD). From 2005 to 2008 studied in Cork Institute of Technology, Applied Physics Department, Ireland. Since 2008 he is member of Committee on Radio Astronomy Frequencies, an Expert Committee of the European Science Foundation. He is author of 11 scientific publications and patents. Research interests: radio astronomy, Active Galactic Nuclei, wind measurements and modeling, acoustic noise of wind power parks, mathematical modeling, programming.

E-mail: vladislavsb@ venta.lv

Sabīne Upnere, Normunds Jēkabsons, Roberts Joffe, Valerijs Bezrukovs, Vladislavs Bezrukovs. Vēja ietekmes analīze uz radioastronomiskajiem novērojumiem Irbenes radioteleskopu kompleksā.

Izpēte veikta Irbenē, Ventspils Augstskolas radioastronomijas centrā, kurā darbojas divi paraboliski radioteleskopi - RT-32 (32 m augsta antena ar virsmas laukumu $\left.800 \mathrm{~m}^{2}\right)$ un RT-16 (16 m augsta antena ar virsmas laukumu $\left.201 \mathrm{~m}^{2}\right)$. Centrā jau kopš 2007. gada tiek veikta radioteleskopa RT-16 spoguḷa sistēmas deformāciju modelēšana un tiek vākti statistikas dati par vēja ātrumu, izmantojot meteoroloǵisko torni observatorijas tuvumā.

Radioastronomiskie pētījumi ir ḷoti jūtīgi pret virsmas precizitāti, pat nelielas deformācijas var ievērojami samazināt antenu veiktspēju. Radioteleskopa konstrukcijas skar dažāda veida slodzes: gravitāte, vējš un temperatūras svārstības. Šajā publikācijā tiek analizēti rezultāti, kas iegūti modelējot vēja radītās deformācijas uz RT-16 radioteleskopa spoguḷa sistēmu. Lai modelētu turbulentu gaisa plūsmu ap teleskopu, tiek izmantots skaitliskās hidrodinamikas (Computational Fluid Dynamic) modelis un gal̄̄go tilpumu metode. Parciālo diferenciālvienādojumu risināšanai tika pielietots atvērtā koda skaitliskās hidrodinamikas instruments OpenFOAM. Aprēkini tika veikti, novietojot teleskopa spoguli dažādos lenkos. Modela sarežǧîtība slēpjas apstāklī, ka tiek apskatīta turbulenta gaisa plūsma. Šajā izpêtē turbulentajai plūsmai bija relatīvi zems ātrums, līdz ar to gaisa blīvums saglabājās praktiski nemainīgs. Turpmāk tiek plānots izveidot vienotu hidrodinamikas un cietvielu modeli gan RT-16, gan RT-32 antenai. 